Vol. 2 | No. 2 | 2021 | Hal. 90-95

\title{
PEMANFAATAN SOSIAL MEDIA SEBAGAI MEDIA PEMASARAN ONLINE PRODUK BATU BATAKO
}

\author{
Mohamad Bastomi*, Irpan Musodikin \\ Fakultas Ekonomi dan Bisnis, Universitas Islam Malang \\ *korespondensi email: mb.tomi@unisma.ac.id
}

\begin{abstract}
ABSTRAK
Media sosial memang sangat diminati UMKM untuk mengembangan bisnisnya. Media sosial mempunyai pengaruh yang sangat besar, masyarakat lebih cepat menerima informasi lewat internet. Dengan akses yang mudah dan cepat hal ini dimanfaatkan oleh para pengusaha kecil UMKM untuk lebih berani mempromosikan produk produknya karena jaringan internet sangat luas dan tidak ada batasan waktu dan wilayah hingga menjadikan media pemasaran yang efektif. Kegiatan ini untuk mengetahui bagaimana pemanfaatan media sosial pemasaran produk UMKM di dusun munduk. Adapun tujuan program ini adalah untuk mengenalkan produk produk UMKM kepada masyarakat luas agar mendapat potensi pasar yang lebih besar. Hal ini dilakukan dengan tujuan untuk mengetahui pemasaran. Setelah survey Kelompok KSM Tematik 40 diajak Pak hlipur Untuk melihat langsung proses pemasaran produk dan dikenalkan dengan bu fitri selaku pemilik UMKM. Tahap selanjutnya Kelompok KSM Tematik 40 membantu memasarkan produk serta memberikan inovasi mengenalakan marketples. Sebelumnya pelaku usaha Umkm ini hanya menjual pasir, dan Kelompok KSM Tematik-40 memberikan masukan untuk memproduksi beberapa produk batako dan paping.
\end{abstract}

Kata Kunci: sosial media; edukasi UMKM; pemasaran online

\section{PENDAHULUAN}

Pandemi Covid-19 memiliki dampak besar terhadap segala aspek dan sektor di kehidupan masyarakat terutama pada sektor ekonomi (Safi et al., 2021). Menteri Keuangan Sri Mulyani mengatakan ada 3 dampak besar ekonomi pada pandemi Covid-19. Pertama, berdampak pada konsumsi rumah tangga atau daya beli masyarakat yang jatuh. Kedua, investasi ikut melemah ditengah ketidakpastian pandemi Covid-19. Dan ketiga, pelemahan ekonomi seluruh dunia yang membuat ekspor Indonesia terhenti (Situmorang, 2020). Dikarenakan menurunnya kegiatan masyarakat di luar rumah, maka secara otomatis juga menimbulkan penurunan jumlah pembeli pada suatu usaha. Sehingga pendapatan yang diperoleh menjadi berkurang. Dampak tersebut tidak hanya dirasakan oleh industri besar, pandemi virus Corona juga memberikan dampak terhadap pelaku Usaha Mikro, Kecil, dan Menengah (UMKM) di Indonesia (Suryani, 2020).

Zaman sekarang adalah era globalisasi, era kemajuan ilmu pengetahuan dan teknologi yang telah menimbulkan persaingan dalam berbagai bidang yang menuntut masyarakat Indonesia untuk memantapkan diri dalam meningkatkan kualitas dan sumber daya manusia yang unggul, mampu berdaya saing menguasai ilmu pengetahuan dan 
teknologi mempunyai etos kerja yang tinggi serta mau bersaing dalam tantangan kehidupan yang semakin ketat (Aryo, 2020; Sari et al., 2021).

Pelaksanaan kegiatan KSM Tematik 40 ini dilakukan di dusun munduk Negara bali dengan Tema "Optimalisasi Peran UMKM Mewujudkan Desa Tangguh". Pemilihan lokasi tersebut sudah direncanakan oleh tim dan memang sudah dilakukannya observasi sebelumnya terhadap wilayah tersebut. Adapun permasalahan yang terjadi di masyarakat khususnya wilayah Dusun munduk sebagian Pedagang kecil harus menutup tokonya sementara waktu. Dan terjadi Pemutusan Hubungan Kerja (PHK) yang merupakan dampak yang dialami kurang lebih hampir sebagian dari masyarakat, sehingga diantaranya masyarakat tersebut beralih profesi untuk membuka usaha secara mandiri/UMKM.

Pada era digital, media sosial saat ini telah menjadi trend dalam komunikasi pemasaran (Purbohastuti, 2017). Media sosial adalah sebuah media online, dengan para penggunanya bisa dengan mudah berpartisipasi, berbagi, dan menciptakan isi meliputi blog, jejaring sosial, wiki, forum dan dunia virtual (Cahyono, 2016). Blog, jejaring sosial, dan wiki merupakan bentuk media sosial yang paling umum digunakan oleh masyarakat di seluruh dunia. Media sosial yang saat ini menjadi tren anak-anak muda mengekspresikan diri menjadi peluang besar sebagai media iklan maupun promosi bisnis. Media sosial seperti Facebook, Instagram, Twitter, WhatsApp, dan lain sebagainya sekarang banyak dimanfaatkan untuk media bisnis, baik dari produk produk yang sudah ternama hingga produk buatan sendiri (Febrian et al., 2021).

Media sosial memang sangat diminati UMKM untuk mengembangan bisnisnya. Media sosial mempunyai pengaruh yang sangat besar, masyarakat lebih cepat menerima informasi lewat internet (Elvina, 2015; Purwidiantoro et al., 2016). Dengan akses yang mudah dan cepat hal ini dimanfaatkan oleh para pengusaha kecil UMKM untuk lebih berani mempromosikan produk produknya karena jaringan internet sangat luas dan tidak ada batasan waktu dan wilayah hingga menjadikan media pemasaran yang efektif.

Saat pandemi Covid-19 terjadi dan masih berlangsung, jumlah tersebut akan terus meningkat seiring dengan adanya kebijakan jaga jarak fisik yang membuat masyarakat melakukan kegiatannya sacara daring. Oleh karena itu media sosial dapat dijadikan sebagai alat untuk mengembangkan dan mengoptimalkan usaha terutama usaha mikro kecil menengah (UMKM) khususnya untuk mempromosikan usaha-usahanya.

Dengan adanya pengenalan sistem pemasaran digital ini diharapkan para pelaku UMKM di Dusun Munduk ini bisa lebih mengoptimalkan dan meningkatkan pengetahuan mengenai sistem pemasaran digital atau sistem pemasaran online, sebab melalui sistem pemasaran digital atau sistem pemasaran online produk-produk dari UMKM akan dapat lebih dikenal oleh masyarakat, pemesanan bisa dilakukan secara online, sehingga dapat memudahkan pembeli dan pelaku UMKM dalam bertransaksi jual beli ditengah pandemi Covid-19 saat ini.

Ditengah Pandemi Covid-19 ini, pelaku UMKM setidaknya mampu mengandalkan pemasaran produk secara online melalui media sosial untuk mengurangi aktivitas di luar rumah dan tetap bisa bekerja dirumah. Namun pada kenyataannya, masih banyak ditemukan masyarakat yang belum memahami cara pemasaran produk-produk tersebut melalui media sosial. Oleh karena itu mahasiswa KSM Tematik 40 turun langsung ke lokasi tersebut untuk membantu meningkatkan dan mengembangkan perekonomian masyarakat tersebut agar dapat tercapainya produktifitas yang aktif kembali di masa New Normal melalui pendampingan terhadap masyarakat yang memiliki usaha dalam memasarkan produk-produknya melalui media online.

Berdasarkan latar belakang tersebut di atas, maka tujuan KSMT-40 ini yang dilakukan di dusun munduk ini adalah untuk memberikan pemahaman tentang teknik 
mempergunakan media sosial serta tata cara memasarkan produk-produk tersebut demi ketahanan kehidupan mereka di masa pandemi covid-19 ini.

\section{METODE}

Pelaksanaan kegiatan pengabdian dilakukabn dengan menerapkan bebrapa metode, seperti sosialisasi, edukasi, dan pendampingan Sebelum Kelompok KSM Tematik 40 melakukan kegiatan UMKM di dusun munduk, kami mengadakan Sosialisasi terlebih dahulu dengan tujuan untuk memberikan pemahaman bagi pelaku UMKM untuk lebih mengedepankan inovasi mengingat faktor tersebut sangat menentukan keberhasilan dalam bersaing di pasar. Memberikan edukasi pelaku usaha mikro terkait pemanfaatan media sosial bukan suatu hal yang mudah. Kita mesti punya kemampuan untuk mau belajar dalam meningkatkan skill atau keahlian dibidang lainnya, agar bisa terus berinovasi dan menghasilkan produk yang menarik yang nantinya mampu menarik pengguna media sosial berminat membeli produk yang kita tawarkan. Berikut beberapa rangkaian kegiatan yang diadakan di Dusun munduk. Bahan yang digunakan untuk proses pembuatan batako: (1) Pasir, (2) semen, (3) cetakan batako, dan (4) Air.

Proses Pembuatan batako:

1. Taburkan sejumlah pasir yang sudah ada

2. Tungkan semen diatas pasir dan aduk keduanya dan aduk sampai merata

3. Adukan menjadi gundukan sesui cetakan yg sudah di siapkan

\section{HASIL DAN PEMBAHASAN}

Media sosial memang sangatdiminati UMKM untuk mengembangan bisnisnya. Media sosial mempunyai pengaruh yang sangat besar, masyarakat lebih cepat menerima informasi lewat internet. Dengan akses yang mudah dan cepat hal ini dimanfaatkan oleh para pengusaha kecil UMKM untuk lebih berani mempromosikan produk produknya karena jaringan internet sangat luas dan tidak ada batasan waktu dan wilayah hingga menjadikan media pemasaran yang efektif.

Dengan memanfaatkan media online ini berupaya untuk mengatasi masalah penurunan ekonomi yang dialami oleh warga desa airkuning. Tahap pertama yaitu melakukan survey ke dusun munduk. Penelitian ini memiliki tujuan untuk: mendapat gambaran mengenai strategi pemasaran untuk meningkatkan daya saing, dan untuk mengetahui seberapa efektif pelaksanaan strategi pemasaran yang telah dilakukan. Penelitian ini dilakukan di toko mutiaralaut banjar munduk. Teknik pengumpulan datanya dengan dokumentasi, wawancara dan observasi, jenis penelitian deskriptif. Hasil dari analisis efektifitas strategi pemasaran menunjukkan adanya peningkatan total penjualan dari tahun ke tahun dan dijadikan sebagai acuan efektifitas strategi pemasaran dalam persaingan antar umkm.

Pada tahap ini pelaksanaan kegiatan mengisi buku tamu dan meminta informasi kepada ibu ftri selaku pemilik UMKM. Hal ini dilakukan dengan tujuan untuk mengetahui batako yg berulitas, baik dan kuat untuk dipasaran. Setelah survey Kelompok KSM Tematik 40 diajak bpk halipur Untuk melihat langsung proses pembuatan produk dan dikenalkan dengan bu fitri selaku pemilik Umkm.Tahap selanjutnya Kelompok KSM Tematik 40 membantu pembuatan produk serta memberikan inovasi dan membuat promosi. Sebelumnya pelaku usaha Umkm ini hanya menjual pasir, dan Kelompok KSM Tematik-40 memberikan masukan untuk memproduksi beberapa produk seperti batako dan paping

Kemudian Kelompok KSM Tematrik 40 membantu memasarkan produk melalui media sosial berupa Whatsaap, Instagram, Facebook dan menawarkan kepada werga. Kami 
menjual produknya dengan harga 1700 Rupiah dan keuntungan diberikan kepada Bu Fitri yang mengalami penurunan pendapatan karena pandemi covid-19.

Di dunia digital ini semakin banyak eccomers dan market place membuat perkembangan usaha kecil menengah (UKM) semakin pesat. Tanpa adanya usaha kecil menengah (UKM) roda perekonomian macet dan memberikan banyak dampak pada usaha skala besar. Mahasiswa KKN Tematik Unisma memberikan edukasi terhadap Bu fitri pelaku usaha yang minim tentang cara memasarkan produk melalui media online atau market place serta memberikan masukan.

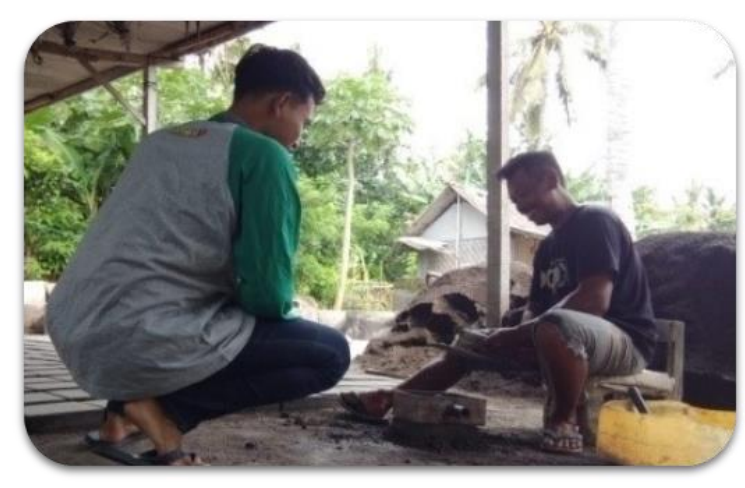

Gambar 1. pembuatan batako

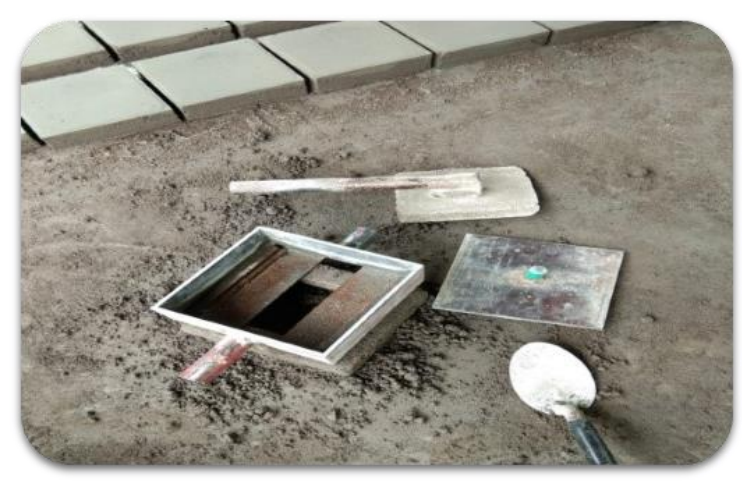

Gambar 2. alat cetakan

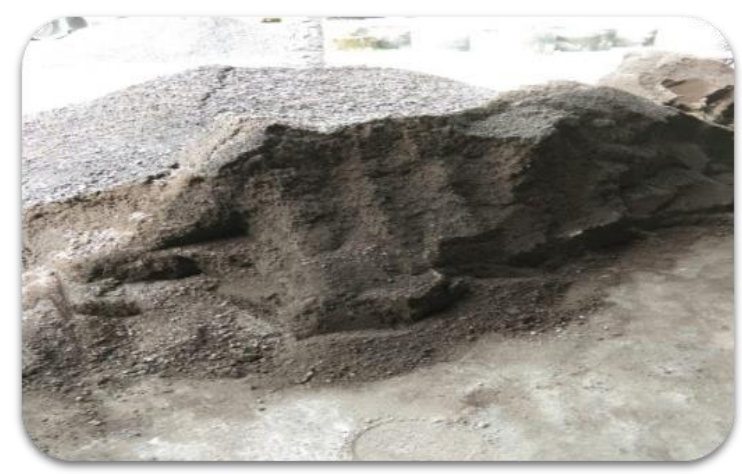

Gambar 3. pasir 


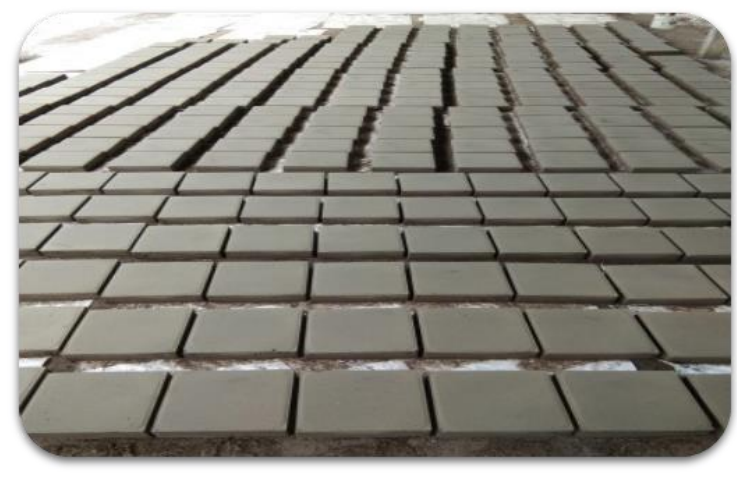

Gambar 4. Batu batako

\section{KESIMPULAN}

Dari pembahasan tersebut, dapat disimpulkan bahwa Selama Pandemi Covid-19 memiliki dampak besar terhadap segala aspek dan sektor di kehidupan masyarakat terutama pada sektor ekonomi. Menteri Keuangan Sri Mulyani mengatakan ada 3 dampak besar ekonomi pada pandemi Covid-19. Pertama, berdampak pada konsumsi rumah tangga atau daya beli masyarakat yang jatuh. Kedua, investasi ikut melemah ditengah ketidakpastian pandemi Covid-19. Dan ketiga, pelemahan ekonomi seluruh dunia yang membuat ekspor Indonesia terhenti. Dikarenakan menurunnya kegiatan masyarakat di luar rumah, maka secara otomatis juga menimbulkan penurunan jumlah pembeli pada suatu usaha. Sehingga pendapatan yang diperoleh menjadi berkurang. Dampak tersebut tidak hanya dirasakan oleh industri besar, pandemi virus Corona juga memberikan dampak terhadap pelaku Usaha Mikro, Kecil, dan Menengah (UMKM) di Indonesia.

\section{UCAPAN TERIMA KASIH}

Terimakasih Kepada Saipur Rahman Selaku Klian banjar, Bu Fitri Pelaku Usaha UMKM.

\section{DAFTAR RUJUKAN}

Aryo, W. B. (2020, April 29). Membangun SDM Indonesia Membangun Sinergitas. Kemenko $P M K$. https://www.kemenkopmk.go.id/membangun-sdm-indonesia-membangunsinergitas

Cahyono, A. S. (2016). Pengaruh media sosial terhadap perubahan sosial masyarakat di Indonesia. Jurnal Publiciana, 9(1), 140-157. http://www.jurnalunita.org/index.php/publiciana/article/download/79/73

Elvina. (2015). Pengaruh Penggunaan Media Sosial terhadap Pengembangan Usaha Kecil Menengah (UKM). ECOBISMA (Jurnal Ekonomi, Bisnis Dan Manajemen), 2(1), 106-118. https://doi.org/10.36987/ecobi.v2i1.722

Febrian, A., Lina, L. F., Safitri, V. A. D., \& Mulyanto, A. (2021). Pemasaran digital dengan memanfaatkan landing page pada perusahaan start-up. Jurnal Inovasi Hasil Pengabdian Masyarakat https://doi.org/10.33474/jipemas.v4i3.10103

(JIPEMAS),

$4(3)$.

Purbohastuti, A. W. (2017). Efektivitas Media Sosial Sebagai Media Promosi. Ekonomika, 12(2), 212-231. https://doi.org/10.35448/jte.v12i2.4456

Purwidiantoro, M. H., Kristanto, D. F., \& Hadi, W. (2016). Pengaruh Penggunaan Media Sosial Terhadap Usaha Kecil Menengah (UKM). AMIK Cipta Darma Surakarta, 1(1), 30-39. http://journal.amikomsolo.ac.id/index.php/ekacida/article/view/19/11

Safi, I., Candra, A. I., Widodo, S. R., Santoso, A., Heryanto, B., Winarti, E., \& Rahmadi, A. N. (2021). Pembuatan masker dan bilik disinfektan sebagai upaya membantu 
masyarakat terdampak covid-19. Jurnal Inovasi Hasil Pengabdian Masyarakat (JIPEMAS), 4(1), 36-45. https://doi.org/10.33474/jipemas.v4i1.7524

Sari, W. E., Yulianto, Junirianto, E., Franz, A., Karim, S., \& Khamidah, I. M. (2021). Video branding untuk promosi usaha mikro kecil menengah (UMKM). Jurnal Inovasi Hasil Pengabdian Masyarakat (JIPEMAS), 10-18. https://doi.org/10.33474/jipemas.v4i1.7174

Situmorang, A. P. (2020). Sri Mulyani: Corona Beri 3 Dampak Besar ke Ekonomi Indonesia. Liputan6.Com.

Suryani, E. (2020). Analisis Dampak Covid-19 terhadap UMKM (Studi Kasus : Home Industri Klepon di Kota Baru Driyorejo). Jurnal Inovasi Penelitian, 1(8), 1591-1596. https://doi.org/10.47492/jip.v1i8.272 